\title{
Kampinos National Park: a risk area for spotted fever group rickettsioses, central Poland?
}

\author{
Joanna Stańczak ${ }^{1}$ - Beata Biernat ${ }^{1}$ - Anna Matyjasek ${ }^{1,2}$ • \\ Maria Racewicz $^{1} \cdot$ Marta Zalewska $^{3} \cdot$ Daria Lewandowska $^{1}$
}

Received: 25 May 2016/Accepted: 3 August 2016/Published online: 8 September 2016

(C) The Author(s) 2016. This article is published with open access at Springerlink.com

\begin{abstract}
Ixodid ticks are important vectors of a variety of bacterial and protozoan pathogens which cause infections in humans. In this study, altogether 1041 questing Ixodes ricinus $(\mathrm{n}=305)$ and Dermacentor reticulatus ticks $(\mathrm{n}=736)$, sympatrically occurring in Kampinos National Park (KPN), central-east Poland, were analyzed by PCR for Rickettsia species. Overall, the pathogen prevalence in ticks was $27.5 \%$ for I. ricinus and $42.8 \%$ for $D$. reticulatus. Sequencing analysis showed that the first tick species was exclusively infected with $R$. helvetica, whereas the latter was infected with $R$. raoultii. These organism may pose a threat for populations exposed to ticks. Preliminary results of a serosurvey of $74 \mathrm{KPN}$ employees, inhabitants and visitors from the same area showed a $31.1 \%$ total seroprevalence against SFG rickettsiae compared to $13.3 \%$ seropositive blood donors of the control group. Risk factors significantly associated with IgG seropositivity were: occupational exposure to ticks $(p=0.002)$, frequency of tick bites $(p=0.02)$ and male gender $(p=0.005)$. Seropositive and seronegative individuals occupationally exposed to ticks did not differ significantly with respect to age and years of employment.
\end{abstract}

Keywords Dermacentor reticulatus $\cdot$ Ixodes ricinus $\cdot$ Rickettsia helvetica $\cdot$ Rickettsia raoultii - Spotted fever group rickettsiae - Seroprevalence - Kampinos National Park · Poland

Joanna Stańczak

astan@gumed.edu.pl

1 Department of Tropical Parasitology, Institute of Maritime and Tropical Medicine, Medical University of Gdańsk, Powstania Styczniowego 9B Str., 81-519 Gdynia, Poland

2 Chair and Clinic of Internal Medicine, Connective Tissue Diseases and Geriatrics, Medical University of Gdańsk, Dębinki 7 Str., 80-211 Gdańsk, Poland

3 Department of Environmental Hazards Prevention and Allergology, Medical University of Warsaw, Banacha 1a Str., 02-091 Warsaw, Poland 


\section{Introduction}

Spotted fever group (SFG) rickettsioses in humans are caused by small, obligate intracellular Gram-negative bacteria of the genus Rickettsia (Rickettsiaceae; Rickettsiales). Most SFG rickettsiae are tick-associated, except Rickettsia akari (mite-borne) and R. felis (flea-borne). Maintenance of rickettsiae in tick vectors occurs by both vertical and horizontal transmission. Therefore, larvae, nymphs and adults may all be infective for susceptible hosts, including humans. Rickettsiae infecting the ticks' salivary glands are transmitted to the host during feeding (Brouqui et al. 2007). Thus, ixodid ticks serve both as the main vectors and reservoir hosts for pathogens.

At least eight human rickettsial pathogens circulate in ticks in different and often overlapping parts of Europe, including $R$. conorii, $R$. massiliae, $R$. slovaca, $R$. raoultii, $R$. sibirica sibirica, $R$. sibirica mongolotimonae, $R$. helvetica, $R$. rioja, and possibly others (Eremeeva and Dusch 2015). Four of them ( $R$. helvetica, $R$. raoultii, $R$. massiliae, $R$. slovaca) have been so far detected in ticks in Poland (Chmielewski et al. 2009; Mierzejewska et al. 2015; Rymaszewska and Piotrowski 2013; Stańczak et al. 2008). In humans, tick-borne rickettsioses (TBR) have no pathognomonic signs, but may cause a suggesting spectrum of clinical signs: fever, headache, rash, inoculation eschar and enlarged cervical lymph nodes. Acute febrile illness, meningitis and a fatal perimyocarditis, caused by $R$. helvetica have been reported from Sweden (Nilsson 2009; Nilsson et al. 1999, 2010, 2011) and France (Fournier et al. 2000), whereas R. monacensis has been isolated so far from three patients with Mediterranean spotted fever-like illness in Spain and in Italy (Jado et al. 2007; Madeddu et al. 2012). Rickettsia slovaca and $R$. raoultii are recognized etiologic agent of tick-borne lymphadenopathy (TIBOLA) (Lakos 1997), the disease also known as Dermacentor-borne necrosis erythema and lymphadenopathy (DEBONEL) (Ibarra et al. 2006) or scalp eschar and neck lymphadenopathy after tick bite (SENLAT) (Angelakis et al. 2010). Human cases due to $R$. slovaca or, rarely, $R$. raoultii infections have been reported from Hungary, France, Spain, Portugal, Italy and Germany (Lakos 1997; Oteo et al. 2004; Parola et al. 2009; Rieg et al. 2011; Selmi et al. 2008; de Sousa et al. 2013).

According to the Polish regulations the reporting and registration of rickettsioses are obligatory. In 2006-2012, five cases of various SFG rickettsioses, including two imported from South Africa, were reported in Poland. These infections have been recognized in Mazovia (three cases) and Lower Silesia (two cases). Detected rickettsiae have been classified as: $R$. conorii, $R$. slovaca, $R$. raoultii and $R$. africae (Mączka et al. 2013).

The purpose of this work was to evaluate risk of human exposure to Rickettsia spp. infection by investigating these bacteria in ticks and antibodies against rickettsiae in individuals presumably exposed to tick bites. For this purpose, a highly frequented recreational area, Kampinos National Park (Kampinoski Park Narodowy) (KPN), was chosen as a study area. This is an exceptional national park, as it encompasses forests directly adjacent to Warsaw (Warszawa), the capital of Poland and, as a natural recreational hinterland, is frequently visited by its inhabitants and tourists.

\section{Materials and methods}

\section{Study area}

Kampinos National Park (KNP) [52 $\left.18^{\prime} 21^{\prime \prime} \mathrm{N}, 20^{\circ} 36^{\prime} 32^{\prime \prime} \mathrm{E}\right]$ (Fig. 1) is the largest natural area in Poland. It covers 38,544 ha, including the ancient Kampinos Primeval Forest 
(Puszcza Kampinoska), and forests account up to almost $73 \%$ of the Park's surface. In 2000, KPN was added to the list of UNESCO Biosphere Reserves, and it is also a part of the Nature 2000 network. It is characterized by a varied landscape, dominated by two contrasting elements in the direct vicinity — sand dunes and marshes (extensive peat-bogs). The dunes are covered by pine forests, while the peat-bogs by deciduous forests, containing mainly alder cars, and marshy meadows. There are also some areas of wet-ground forest, which add more variety to the forest flora. The park boundaries are open along practically entire length, making extensive human penetration possible. Among visitors walkers represent $27 \%$ of the total. The tourist traffic is of an estimated one million people per year. Moreover, as many as $30 \%$ of "visitors" are illegal pickers of berries and wild fungi. Some area of the Park is owned by farmers, who live in the villages within the park boundaries (together they make ca. 3000 inhabitants). Thus, the contact between people and ticks in the KNP is frequent.

\section{Tick collection}

Questing ticks were collected by the standard flagging method (white flannel blanked $1 \times 0.75 \mathrm{~m}$ ) at 20 different sites (Fig. 1; Table 1) in April-May 2012/2013. In each site, ticks were collected by three persons for $20 \mathrm{~min}$. Attached specimens were removed with forceps and put into sealed vials, each specimen separately. In the laboratory, ticks were killed by rapid immersion in a hot water, identified to species level using standard morphological identification key (Siuda 1993), categorized by site of collection and a developmental stage, and then preserved in $70 \%$ ethanol for further molecular investigations.

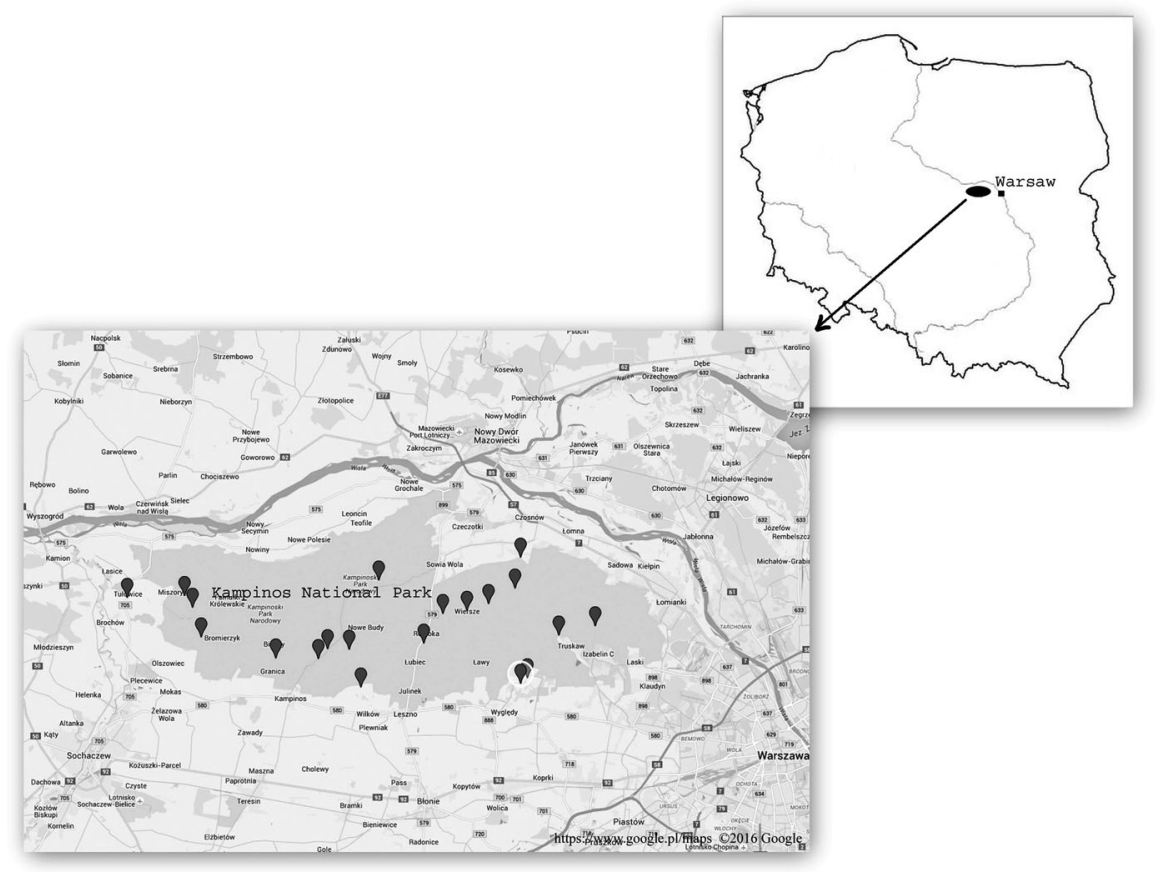

Fig. 1 The map of the sampling points in Kampinos National Park, Poland 


\section{DNA extraction}

All ticks were analysed individually. Extraction of total DNA was done by boiling crushed specimens in ammonium hydroxide $\left(\mathrm{NH}_{4} \mathrm{OH}\right)$ (Guy and Stanek 1991; Rijpkema et al. 1996). Concentrations of DNA were measured with spectrophotometric method (NanoDrop 1000 spectrophotometer, Thermo Scientific, USA). The obtained lysates were stored at $-20{ }^{\circ} \mathrm{C}$ until use as templates for the molecular investigations.

\section{Real time PCR}

All tick samples were individually screened by real time PCR for the citrate synthase encoding gene ( $g l t A)$ specific for all Rickettsia spp. Primers Rick GltA-f (5'-ATCCTACATGCCGATCATGAGC-3') and Rick GltA-r (5'-GTGAGCAGGTCCCCAAAGTG-3') were designed to target a 123-bp part of the gene with TaqMan probe (5-HEXATGCTTCTACTTCAACAGTCCGAATTGCCG-BHQ1-3') (Biernat et al. 2016a).

Reaction mixtures and cycling conditions were as previously described (Biernat et al. 2016a). Negative and positive controls were included in all runs. Rickettsia-positive control was constructed by cloning the 123-bp PCR amplicon into a circular pJet1.1 plasmids (Fermentas, USA) (Biernat et al. 2016a). Reactions were performed in the Mx3005P Real-Time QPCR System (Stratagene, CA, USA).

\section{Detection and identification of Rickettsia spp.}

Most real time PCR-positive samples were subsequently rerun using semi nested PCR and nested PCR assays to obtain longer amplicons for further DNA sequencing. Semi nested PCR was conducted with three primers of which Ric and Ric U8 yielded a 1385-bp fragment encompassing almost the complete 16S rRNA gene, while Ric and Ric Rt flanked a 757 bp fragment (Nilsson et al. 1997). In the nested PCR, primers SLO1F/SLO1R and SLO2F/SLO2R, targeting a fragment (355 bp) of ompA gene specific for $R$. slovaca and $R$. raoultii, were used as the outer and inner pairs, respectively (Raoult et al. 2002). Resulted

Table 1 Prevalence of Rickettsia spp. in Ixodes ricinus and Dermacentor reticulatus ticks collected in Kampinos National Park in 2012/2013

\begin{tabular}{llcl}
\hline Tick species & Developmental stage & No. tested & No. $(\%)$ infected \\
\hline Ixodes ricinus & Nymphs & 6 & 0 \\
& Females & 155 & $44(28.4)$ \\
& Males & 144 & $40(27.8)$ \\
Dermacentor reticulatus & Subtotal & 305 & $84(27.5)$ \\
& Females & 385 & $163(42.3)$ \\
& Males & 351 & $152(43.3)$ \\
Total & Subtotal & 736 & $315(42.8)$ \\
& Nymphs & 6 & 0 \\
& Females & 540 & $206(38.1)$ \\
& Males & 495 & $193(40.0)$ \\
& Total & 1041 & $399(38.3)$ \\
\hline
\end{tabular}


amplicons of $355 \mathrm{bp}$ were considered positive. Additionally, a few of the positive samples were analyzed by the conventional PCR using the primer pair RpCS.877p and RpCS.1258n amplifying a fragment of the citrate synthase encoding gene $(\mathrm{gltA})$, which has conserved regions shared by all known Rickettsia species (Regnery et al. 1991). DNA products of $380 \mathrm{bp}$ were considered to be positive results.

All amplifications were carried out in the GeneAmp ${ }^{\circledR}$ PCR System 9700 (Applied Biosystems, Foster City, CA, USA) as previously described (Biernat et al. 2016b). PCR products were separated on $2 \%$ agarose gels stained with Midori green DNA Stain (Nippon Genetics Europe) and visualized under UV light using the GelDoc-It, Imagine Systems $\mathrm{UV}^{\mathrm{TM}}$ Transluminator (Upland, CA, USA). Rickettsia helvetica and $R$. raoultii positive samples obtained in our previous investigations (Stańczak 2006; Stańczak et al. 2009) and confirmed by the sequence analysis of the PCR products were used as positive controls. Nuclease-free water was added to each run as a negative control.

\section{DNA sequencing}

Chosen positive amplicons were purified using the Clean-Up purification kit (A\&A Biotechnology, Gdynia, Poland), sequenced in both directions with the same primers as used in the semi-nested PCR and nested PCR assays with the ABI Prism ${ }^{\circledR}$ Big Dye ${ }^{\mathrm{TM}}$ Terminator v.3.1 Cycle Sequencing Kit and then analyzed with the ABI PRISM $3130 x L$ genetic Analysers (Applied Biosystem) according to the manufacturer's protocol. Finally, sequences were edited and compared with each other and with corresponding sequences registered in the GenBank database using the NCBI BLAST program (U. S. National Institutes of Health, Bethesda, Maryland) [http://blast.ncbi.nlm.nih.gov/Blast.cgi]. Then consensus sequences were submitted to GenBank.

\section{Seroreactivity to Rickettsia of population exposed to tick-bite}

\section{Study group}

A total of 74 persons differently exposed to tick bites were examined. The group comprised 60 workers of KPN (23 females, 37 males; mean age 47.2 years, range 27-65) and 14 members of their families ( 9 females, 5 males; mean age: 40.1 years, range 9-65) occupationally and recreationally, respectively, exposed to ticks.

As a control group, 30 blood donors ( 8 females, 22 males; mean age 29.8 years, range 18-60) who denied a tick bite 6 months prior to the investigation were examined. They were city dwellers with no Lyme borreliosis history.

Blood samples were taken by venipuncture and sera separated by centrifugation. In addition, EDTA blood samples were obtained from the study group for real time PCR analysis. Samples were stored at $-20{ }^{\circ} \mathrm{C}$ until the time of analysis.

\section{Serological tests}

\section{Immunoenzymatic assay}

The commercial ELISA kits (Spotted Fever Group Rickettsia EIA IgG and IgM Antibody Kit, Fuller Laboratories, Fullerton, CA, USA) were used to detect IgG and IgM antibodies 
against SFG Rickettsia spp. The EIA module wells in this kit utilized a SFG-specific lipopolysaccharide (rLPS) antigen extracted from a members of the SF group, including $R$. rickettsii, $R$. akari, $R$. parkeri, $R$. felis, $R$. montanensis, and others. The tests were carried out according manufacturer's instructions, including the cutoff calibrator instructions. Absorbance was measured at a wave length of $450 \mathrm{~nm}$ on a microtiter plate reader. The obtained values of tested samples were divided by the mean absorbance values of Cutoff Calibrator. The Calibrator was set at an index of 1.0. Index values from 0.8 to 1.2 were considered equivocal (weak positive), above 1.2 as positive and those below 0.8 were considered negative. For analysis, the weak positive results were included into positive group.

\section{Micro-immunofluorescence assay (MIF)}

To detect IgG antibodies to selected antigens of SGF rickettsiae simultaneously, Rickettsia 2-Antigen MIF IgG Antibody Test (Fuller Laboratories) was used. Purified, acetone-fixed antigens of $R$. helvetica and $R$. raoultii used as an individual substrate on the same slide wells were applied as diagnostics antigens. These slides contain Vero-76 cells with 30-40 infected cells per field when using a $40 \mathrm{X}$ lens. The positive and negative controls of human serum used in the procedures were contained in the MIF kits. The assays were performed according to the manufacturer's instructions. Positive control serum was tested in serial dilution to determine their endpoint titer. Fluorescence of the rickettsiae with an intracellular distribution and intensity pattern similar to the positive control was considered as a positive reaction. The test titer started at 1:32 and an antibody titer of $\geq 1: 64$ was considered as positive reaction. All IFA slides were screened by the trained person using a fluorescence microscope (Zeiss).

\section{PCR assay}

EDTA blood samples were screened using real time PCR. DNA extraction was carried out with the Blood Mini kit (A\&A Biotechnology, Gdynia, Poland) template preparation according to the manufacturer's instruction. Obtained templates were stored in -20 until used for real time PCR assays with the same primers and probe like in the case of ticks investigation.

\section{Seroreactivity and association with risk factors}

Each serum donor answered a questionnaire regarding gender, age, ticks exposure (occupational, recreational) and tick bites experienced during the last 12 months ('none', '15 ', ' $6-10$ ', and ' $>10$ '), length and character of employment in the forest, other tick-borne diseases history, and symptoms such as: an eschar at the site of a tick bite, unexplained fever, headache, myalgia or enlarged lymph nodes 4-6 weeks prior to investigation.

\section{Ethical statement}

The study was approved by the Bioethics Committee of Warsaw Medical University (KB/ 189/2013). All individuals who agreed to participate signed their consent form and their personal information was held by Department of Tropical Parasitology, Medical University of Gdańsk. 


\section{Statistical analysis}

All statistical analyses were performed with R (2008; http://www.R-project.org) and Excel. Qualitative variables were presented using frequencies. Regression analysis and analysis of variance with Tukey's multiple comparisons of means for quantitative variables and Fisher's Exact test for qualitative variables were $(\alpha=0.05)$.

\section{Results}

\section{Ticks and tick infection rates}

Altogether 1041 questing ticks were collected during their spring activity season (AprilMay) in 2012/2013 at 20 different collection sites spread all-over KPN. Of them, 736 were identified as D. reticulatus (70.7\%) (385 females and 351 males) and 305 as I. ricinus (29. $3 \%$ ) (155 females, 144 males, 6 nymphs) (Table 1). Dermacentor reticulatus ticks were found at 16 collection sites whereas I. ricinus in 18 of them (Table 2). The first species (93.5\% collected specimens) prevailed in the open areas, meadows, pastures and wastelands (10 collection sites). The second species (62.3\% collected specimens) was dominant in the forested areas (8 collection sites). In two collection sites (mixed stands) both species occurred in comparable numbers (in total 30 vs 25).

All collected ticks were individually screened for the presence of Rickettsia spp. by the real time PCR and rickettsial DNA was detected in $38.3 \%(n=399)$ of them. However, the rate of infection differed by tick species. The infection rate of I. ricinus was $27.5 \%$ $(\mathrm{n}=84 / 305)$, being comparable in females and males (28.4 vs $27.8 \%)$, whereas none of 6 nymphs was positive (Table 1). Prevalence of Rickettsia spp. in D. reticulatus ticks$42.8 \%(\mathrm{n}=315 / 736)$ - was significantly higher than in I. ricinus. The infection rate in male and female ticks also were similar (43.3 vs $42.3 \%$ ) (Table 1).

Depending on collection site, the percentage of infected I. ricinus varied between 16.7 and $47.1 \%$, while in the case of $D$. reticulatus the infection level ranged from 18.8 to $66.7 \%$ (Table 2).

\section{Identification of Rickettsia spp.}

To identify species of Rickettsia, majority of real time PCR-positive samples were subsequently rerun using nested or/and semi nested PCR targeting two genes, 16S rRNA and ompA. As a result, among positive $D$. reticulatus 59 amplicons of $16 \mathrm{~S}$ rRNA-fragment of Rickettsia spp. and 223 amplicons of ompA-fragment were obtained. Of them, a total of 60 samples were sequenced and 55 obtained sequences were compared with those from rickettsia species and strains deposited in GenBank database. Thirty-three sequences showed $100 \%$ homology with the sequences of partial cds of 16S rRNA gene of $4 R$. raoultii strains or isolates: strain RpA4 (acc. no. AF120026) (tick, Russia), strain DnS28 (acc. no. AF120024) (tick, Russia), strain Marne (acc. no. DQ365809) (D. reticulaus, France) and isolate BL029-2 (acc. no. KJ410261) (Hyalomma asiaticum, China). The representative sequence was submitted to GenBank under the accession no. KX024760. Twenty sequences were $100 \%$ identical with numerous homologous fragments of ompA gene of $R$. raoultii (former Rickettsia sp. RpA4), including Rickettsia sp. RpA4 (ac. no. AF120022) detected for the first time in hard ticks in Russia, isolate TG82 (acc. no. 
Table 2 Rickettsia spp. prevalence in ticks collected in different sites of Kampinos National Park in 2012/2013

\begin{tabular}{llllr}
\hline Collection site & Position NE & $\begin{array}{l}\text { I. ricinus } \\
\text { No. tested/no. } \\
(\%) \text { infected }\end{array}$ & $\begin{array}{l}\text { D. reticulatus } \\
\text { No. tested/no. } \\
(\%) \text { infected }\end{array}$ & $\begin{array}{l}\text { Total } \\
\text { No. tested/no. } \\
(\%) \text { infected }\end{array}$ \\
\hline Famułki Brochowskie & $52.3102,20.3637$ & $21 / 6(28.6)$ & $1 / 0$ & $22 / 6(27.2)$ \\
Górczyńska Droga & $52.3022,20.5045$ & $18 / 5(27.7)$ & 0 & $18 / 5(27.7)$ \\
Górki-Zamczysko & $52.3017,20.5287$ & $41 / 10(24.4)$ & $5 / 1(\mathrm{nc})$ & $46 / 11(23.9)$ \\
Granica & $52.2960,20.4466$ & $17 / 8(47.1)$ & $63 / 19(30.2)$ & $80 / 27(33.8)$ \\
Janówek & $52.3433 ; 20.7132$ & $3 / 1(\mathrm{nc})$ & $14 / 6(42.9)$ & $17 / 7(41.2)$ \\
Kiścinne & $52.3261 ; 20.6328$ & $1 / 0(\mathrm{nc})$ & $104 / 52(49.5)$ & $105 / 52(49.1)$ \\
Adamówek + Łosia W. & $52.3642 ; 20.7192$ & $25 / 6(24.0)$ & $133 / 38(28.6)$ & $158 / 44(27.8)$ \\
Korfowe & $52.2762 ; 20.5416$ & $43 / 8(18.6)$ & 0 & $43 / 8(18.6)$ \\
Łąki Tułowickie & $52.3369 ; 20.2813$ & 0 & $12 / 8(66.7)$ & $12 / 8(66.7)$ \\
Mariew & $52.2826 ; 20.7272$ & $23 / 6(26.1)$ & $27 / 12(44.4)$ & $50 / 18(36.0)$ \\
Miszory & $52.3381 ; 20.3455$ & $11 / 3(27.3)$ & $132 / 73(55.3)$ & $143 / 76(53.1)$ \\
OOŚ Narty & $52.2953,20.4940$ & $27 / 7(25.9)$ & 0 & $27 / 7(25.9)$ \\
Roztoka-Parking & $52.3061 ; 20.6117$ & $13 / 5(38.5)$ & 0 & $13 / 5(38.4)$ \\
Sieraków & $52.3178 ; 20.8025$ & $12 / 4(33.3)$ & $13 / 7(53.8)$ & $25 / 11(44.0)$ \\
Stara Dąbrowa & $52.3487 ; 20.5618$ & $15 / 6(40)$ & $1 / 0$ & $16 / 6(37.5)$ \\
Truskaw & $52.3114 ; 20.7619$ & $12 / 2(16.7)$ & $1 / 0$ & $13 / 2(15.4)$ \\
Truskawka & $52.3328 ; 20.6836$ & $1 / 0$ & $53 / 25(47.2)$ & $54 / 25(46.3)$ \\
Wiersze & $52.3282 ; 20.6601$ & $8 / 2(\mathrm{nc})$ & $55 / 17(30.9)$ & $63 / 19(30.2)$ \\
Władysławów & $52.3302 ; 20.3541$ & 0 & $46 / 11(23.9)$ & $46 / 11(23.9)$ \\
Wólka & $52.2788,20.7192$ & $14 / 5(35.7)$ & $76 / 46(60.5)$ & $90 / 51(56.7)$ \\
Total & & $305 / 84(27.5)$ & $736 / 315(42.8)$ & $1041 / 399(38.3)$ \\
\hline & & & &
\end{tabular}

$n c$ not calculated (no. ticks tested $<10$ )

KT895942) (D. marginatus, Austria), strain Mol 11-06 (acc. no. JX978435) (Dermacentor sp., Moldova), clone OrecchiellaOZ77 (acc. no. KC700054) (D. marginatus, Italy) and isolate T6 (acc. no. JQ798907) (TIBOLA patient, Hungary). The representative sequence was submitted to GenBank under the accession no. KX051401.Two sequences of ompA gene showed homology amounting to $99.8 \%$ with Rickettsia sp. RpA4 (ac. no. AF120022) from which differed by one ( $\mathrm{T} \rightarrow \mathrm{C}$ in position 163) and two nt ( $\mathrm{A} \leftrightarrow \mathrm{G}$ in positions 172 and 360). These sequences were deposited in the GenBank under the acc. nos. KX051403 and KX051402, respectively.

On the other hand, no positive results were obtained in I. ricinus ticks analyzed with the nested PCR targeting ompA gene. As this gene seems to be not amplified for $R$. helvetica (Roux et al. 1996), negative results suggested that tested $I$. ricinus were infected with this very species. To confirm this suggestion 44 chosen products of 64 semi nested-positive samples were sequenced. The sequence of partial cds 16S rRNA gene obtained from all PCR products matched in $100 \%$ that of $R$. helvetica: clone CsFC (acc. no. GQ413963) (human patient, Sweden), strain IR-671.2-TM (I. ricinus feeding on Turdus merula, Poland), strain IR-698.9-AF (I. ricinus feeding on Apodemus flavicollis, Poland). The consensus sequence was submitted to GenBank under the accession no. KX024759. 
Additionally, randomly chosen positive samples of D. reticulatus $(\mathrm{n}=3)$ and $I$. ricinus $(\mathrm{n}=3)$ were analyzed by the conventional PCR with primers specific for a gene encoding the citrate synthase gltA (RpCS.887p and RpCS.1258n6) (Regnery et al. 1991) and resulted amplicons of $\sim 380 \mathrm{bp}$ were applied for sequencing. Three sequences derived from $D$. reticulatus had $100 \%$ similarity to the gltA gene of $R$. raoultii isolate S2 (acc. no. LC060713) (D. reticulatus, Hungary, Germany), strain T3 (acc. no. KT895941) (D. reticulatus, Austria) and strain Alashankou-112 (acc. no. KT261764) (D. marginatus, China). They differed by one nucleotide $(\mathrm{C} \rightarrow \mathrm{A})$ from $R$. raoultii strain Marne (acc. no. DQ365803) (D. reticulatus, France) and strain Khabarovsk (acc. no. DQ365804) (D. silvarum, Russia). The representative sequence was deposited in Genbank under the accession no KX051404.

Sequences of the gltA gene fragment from the three I. ricinus samples (GenBank acc. no. KX051405) were identical to $R$. helvetica 6 DI76 isolate and 99Bc strain sequences (acc. no. KC007126; JX0406636) from I. ricinus from Germany and Romania.

\section{Seroprevalence}

All 104 sera of the study $(n=74)$ and control $(n=30)$ groups were tested for the presence of the IgM and IgG antibodies against SFG rickettsiae. Of them, the IgM antibodies were detected only in one person of the study group $(1 / 74 ; 1.4 \%)$, a woman recreationally exposed to tick bites, who denied a tick bite at least 2 month prior investigations and did not complain of any symptom characteristic for a rickettsiosis. Moreover, none of the other examined participants reported flulike symptoms, showed fever and/or rash typical for the clinical form of SFG rickettsioses.

Among 74 persons of the two study groups, employees of KPN and the recreational group, the presence of $\mathrm{IgG}$ antibodies was found in 35 and $14.3 \%$ respectively. This difference, however, was statistically insignificant $(p=0.2)$. In the control group of blood donors, the frequency of positive results was of $13.3 \%$, significantly smaller than in the occupationally exposed group $(p=0.04)$ and similar to the recreational group (Table 3 ).

Separately, the prevalence of antibodies within the group of the KNP employees with outdoor activity (foresters, forestry rangers, forestry workers, etc.) $(50 \%)$ was 2.3 times greater than the positivity rate in the group of office workers $(p=0.03)(21.9 \%)$ who only occasionally visit forests doing duty and 3.5 times higher than in other individuals exposed to ticks during leisure activity $(14.3 \%)$; the difference was statistically significant $(p=0.04)$. Also differences observed in percentage of positive results in male $(51.4 \%)$ and female $(8.7 \%)$ KPN participants were statistically significant $(p=0.002)$ (Table 3$)$.

Within all study groups, a total of $57(77 \%)$ individuals declared at least one tick bite in the year before the study; majority $(\mathrm{n}=54)$ up to 5 bites. The total positivity rate observed among them $(36.8 \%)$ differed significantly $(p=0.008)$ from the positivity rate $(11.8-13.3 \%)$ noted in the group of people $(n=47)$ who denied the tick bite, including 30 persons of the control group. Among employees of KPN, those who denied tick bites in majority consisted of office workers $(n=15 / 16 ; 93.7 \%)$. On the other hand, percentages of seropositive KPN workers did not differ significantly with respect to age $(p=0.6)$ (range 26-70 years) and total years of employment $(p=0.6)$ (range 0.5-45 years). However, it should be taken into consideration that the groups categorized according to different variables were too small for definitive statements. 
Table 3 Prevalence of IgG against SFG rickettsiae antigen in the KPN employees differently exposed to tick bites, recreational and control groups according to gender

\begin{tabular}{lrrr}
\hline Study groups & \multicolumn{2}{l}{ No. tested/no. (\%) seropositive } & \multicolumn{1}{c}{ Total } \\
\cline { 2 - 4 } & \multicolumn{1}{l}{ Females } & \multicolumn{1}{c}{ Males } & $28 / 14(50.0)$ \\
\hline KNP employees with outdoor activity & $5 / 2(40)$ & $23 / 12(52.2)$ & $32 / 7(21.9)$ \\
KNP employees with indoor activity & $18 / 0(0.0)$ & $14 / 7(50.0)$ & $60 / 21(35.0)$ \\
Subtotal & $23 / 2(8.7)$ & $37 / 19(51.4)$ & $14 / 2(14.3)$ \\
Recreational group & $9 / 2(22.2)$ & $5 / 0(0.0)$ & $74 / 23(31.1)$ \\
Total & $32 / 4(12.5)$ & $42 / 19(45.2)$ & $30 / 4(13.3)$ \\
Control group & $8 / 1(12.0)$ & $22 / 3(13.6)$ & \\
\hline
\end{tabular}

a Blood donors

\section{Microimmunofluorescence}

MIF test was employed to confirm the presence of anti- $R$. helvetica and/or anti- $R$. raoultii IgG antibodies in ELISA-positive sera and IgG titer $\geq 64$ were considered positive. In serial dilutions from 1:32 to 1:512, the highest detected titer reached 128. This result concerned the only person who tested positive IgM in ELISA test. In 28/34 sera, strong specific fluorescence was observed in titer 1:64 which corresponded with positive ELISA IgG results. Weaker fluorescence in titer 1:64 was observed in 4 sera whereas lower level of antibodies (titer 1:32) was found in one serum sample. All these results corresponded with equivocal ELISA IgG results.

Observed cross-reactivity made differentiation between $R$. helvetica and $R$. raoultii unable.

\section{PCR assay}

None of the blood samples collected from participants was found to be PCR positive for Rickettsia spp.

\section{Discussion}

Ixodes ricinus is the predominating tick species in Poland, distributed throughout the country. It occurs mainly in deciduous and mixed forests, or bushy thickets. Dermacentor reticulatus is found mainly on the eastern side of the Wisła (Vistula) river: in the northeastern and eastern parts of Poland. Recent studies, however, have shown that its range of occurrence is much more extended in western Poland than expected. The north-south strip (belt) in the center of the country seems to be free of this species and is known as "the gap" which divides ticks into two separated populations-western and eastern. In our country $D$. reticulatus exists mainly in open habitats such as mixed swamp forests, midforest glades and meadows, clearings and bushy pastures on small hills among marshes covered with gray willow (Nowak-Chmura and Siuda 2012).

Diverse landscape, reach and variable vegetation, as well as a variety of host animals, including the elk (Alces alces), a symbol of KPN, create in the Park favorable environmental conditions for the development and survival both of I. ricinus and D. reticulatus. 
Results of the present studies confirmed a sympatric occurrence of these two species on the whole area of KNP and the extending range of the meadow ticks on the western side of the Wisła river. Moreover, they showed a high overall prevalence, exceeding $38 \%$, of SFG Rickettsia spp. infection in ticks collected from vegetation. The mean infection rate in $D$. reticulatus $(\sim 43 \%)$ was in agreement with the prevalence range of the pathogen ( $\sim 40-53 \%$ ) previously observed in eastern and western population of $D$. reticulatus in Poland (Mierzejewska et al. 2015; Stańczak 2006; Wójcik-Fatla et al. 2013) and reported from neighboring Belarus (44.5\%) (Reye et al. 2013) and Germany (56.7 \%) (Silaghi et al. 2011). On the other hand, it was much higher than rickettsial infection determined in $D$. reticulatus in Wales and England (27 \%) (Tijsse-Klasen et al. 2011), Slovakia (22.3-27\%) (Špitalská et al. 2012), Hungary (26.8\%) (Sréter-Lancz et al. 2006), and in the Netherlands (6\%) (Hofmeester et al. 2015).

In questing adult $I$. ricinus, the observed prevalence of Rickettsia spp. of $\sim 28 \%$ was higher than that previously reported in I. ricinus ticks from other areas of Poland (1-11.1\%) (Stańczak et al. 2008; Welc-Falęciak et al. 2014), Austria (16.8\%) (Sonnleitner et al. 2013), Germany (11.7-13.7\%) (Silaghi et al. 2011), Slovakia (6.1-11.7\%) (Špitalská et al. 2012, 2016; Švehlová et al. 2014), Wales and England (6.5\%) (Tijsse-Klasen et al. 2011), Sweden (1.5-17.3\%) (Severinsson et al. 2010) and Finland $(1.5 \%)$ (Sormunen et al. 2016). It is worth mentioning, however, that an exceptionally high infection rate of $I$. ricinus with rickettsiae $(52.5 \%)$ was reported in the city of Hamburg, Germany (May and Strube 2014) and in a vegetation-rich dune area in The Netherland: $\sim 66 \%$ (Sprong et al. 2009). All these reports reflect a great spatial variation in prevalence of Rickettsia spp. in European tick populations.

Sequence analysis of fragments of $16 \mathrm{~S}$ rRNA, ompA and gltA genes allowed the identification of Rickettsia species. D. reticulatus was found to be almost exclusively infected with $R$. raoultii (99.8-100 \% homology) whereas $I$. ricinus with $R$. helvetica (100\% identity). These findings are in accordance with results from other European studies, including Slovakian (Švehlová et al. 2014), Austrian (Sonnleitner et al. 2013) and Swedish (Severinsson et al. 2010) investigations.

Dermacentor reticulatus was proved to be the competent vector of $R$. raoultii with a high level of transovarial (90\%) and transstadial transmission (98\%) (Samoylenko et al. 2009). Although $R$. raoultii seems to be the predominant Rickettsia species in meadow ticks, they also may harbor $R$. slovaca and R. helvetica (Dobec et al. 2009; Dobler and Wölfel 2009; Tijsse-Klasen et al. 2013; Špitalská et al. 2012). On the other hand I. ricinus is considered the major reservoir host (Sprong et al. 2009) and vector for R. helvetica, with the transovarial transmission rate up to $100 \%$ (Socolovschi et al., 2009). In Poland, however, and nearby countries this tick is found to be infected also with other Rickettsia species: R. monacensis (Dobler et al. 2009; Reye et al. 2013; Rymaszewska and Piotrowski 2013; Welc-Falęciak et al. 2014; Simser et al. 2002; Sormunen et al. 2016) and, rarely, with $R$. rauoltii and $R$. slovaca (Chmielewski et al. 2009). Moreover, the occurrence of $R$. massiliae, $R$. felis and Rickettsia sp. similar to $R$. bellii was reported in I. ricinus in Germany (Dobler and Wölfel 2009; Sprong et al. 2009).

Evidence of the presence of $R$. raoultii and $R$. helvetica in ticks and observed high infection level indicate potential epidemiological and epizootiological significance of $D$. reticulatus and I. ricinus in Kampinos National Park. To answer the question whether autochthonous transmission of rickettsiae to humans may occur in this area, we conducted a preliminary study of the presence of antibodies against Rickettsia spp. in groups of people differently exposed to ticks. We have shown that seropositivity to rickettsiae was common among them. The prevalences ranged from 13.3 to $50 \%$ were recorded among 
KNP employees with outdoor activity and in office workers who occasionally visit forests doing duty, in individuals exposed to ticks during leisure activity and in the group of blood donors. This suggests that contacts between ticks and humans, and transmission of Rickettsia spp. is frequent. Moreover, persons who denied tick bites at least 6 month prior to the investigation had a seropositivity rate for IgG of 11.8-13.3\%, that confirms once more the well-known clinical observation that tick bites often go unnoticed.

The overall seropositivity rate $(31.1 \%)$ detected in the present study is comparable with that reported in studies performed in eastern Poland, were total $36 \%$ of forestry and agricultural workers were found to be positive (Zając et al. 2013). As arthropod bites and arthropod-borne infections are the frequent occupational hazards among forestry workers, in both studies the seroprevalence was found to be the highest among forestry workers with outdoor activity -50 and $50.7 \%$, respectively. These results were significantly higher than the result obtained for forestry workers from northeastern and southern Poland $(14.7 \%)$ (Podsiadły et al. 2011) as well as from north-eastern Italy (3.9\%) and Alsace in France (9.2\%) (Cinco et al. 2006; Fournier et al. 2000). In Germany, antibodies against different Rickettsia spp. were found in $9.1 \%$ hunters (Jansen et al. 2008). Survey of another risk group, military recruits during their field training period in the highly tick endemic area of Gotland in Sweden, showed that $22.9 \%$ of them had antibodies against $R$. helvetica (Nilsson et al. 2005). The latter result is comparable with the seroprevalence of KPN employees with the advantage of indoor activity.

Moreover, a serosurvey conducted in Danish patients seropositive for Lyme borreliosis showed that $12.5 \%$ of them had positive antibody titers to $R$. helvetica (Nielsen et al. 2004). Finally, in southern Sweden, $10 \%$ patients with erythema migrans (EM) and/or general signs of infection following a tick bite had antibodies against the same rickettsial species (Lindblom et al. 2013). These results correspond with the seropositivity level among KPN visitors, recreationally exposed to the tick bites.

On the other hand, SFG Rickettsia antibody prevalence in blood donors varies as well. In Sweden approximately $1 \%$ of them were seroreactive (Lindblom et al. 2013), whereas in Tyrol, Austria, seroprevalence ranged from 4.8 to $10.6 \%$ (Sonnleitner et al. 2013), and in our control group reached $13.3 \%$.

To explain so high seroprevalence in people occupationally exposed to ticks in eastern Poland, $36 \%$ of the total, Zajac et al. (2013) suggested that they lived in the area where over $50 \%$ of D. reticulatus ticks harbored $R$. raoultii (Wójcik-Fatla et al. 2013) and thus were under significantly increased risk of infection with these rickettsiae. The only case of autochthonous spotted fever described in Poland was cause the most probably by $R$. raoultii (Świtaj et al. 2012), what may support this suggestion. Also in KNP prevalence of $D$. reticulatus infected with $R$. raoultii exceeded $40 \%$. However, D. reticulatus rarely bites humans. None of the individuals surveyed in our study declared to be bitten by this species, although some of them occasionally found these ticks crawling on their clothes. In contrary, majority of them reported I. ricinus bites with a frequency of 1-5 per year. This tick species shows a high affinity for humans and in Poland, of SFG rickettsiae, is almost exclusively infected with $R$. helvetica (Stańczak et al. 2008). Interestingly, prevalence of $R$. helvetica in I. ricinus in KPN $(27.5 \%)$ was comparable or lower than seroprevalence rates in humans differently exposed to tick bites (range 14.3-50\%). This may suggest that seroprevalence in humans does not directly reflect the prevalence in ticks.

In conclusion, on multivariate regression analysis risk factors significantly associated with SFG rickettsiae infection (prevalence of antibodies) were: occupational exposure to ticks $(p=0.02)$, male gender $(p=0.004)$ and frequency tick bites $(p=0.02)$. 
Unfortunately, results of the $R$. helvetica- and $R$. raoultii-specific MIF test did not answer the question which of these two rickettsiae evoke positive immune response in studied groups. MIF has been the serologic gold standard, originally being the means of determining separate species, however SFG rickettsiae cause cross-reactions within the group (Fournier et al. 2000; Hechemy et al. 1989). We did not observe a significant difference in specific fluorescence between $R$. helvetica and $R$. raoultii, and uncertainty about the source of the infection remained. Interestingly, Podsiadły et al. (2011) detected by MIF antibodies to $R$. massiliae in $79 \%$ of the seropositive forestry workers from northeastern and southern Poland. However, R. massiliae is commonly found in Rhipicephalus sanguineus or $R$. turanicus ticks (Cardeñosa et al. 2003) which are absent in Poland. Recently it has been detected in Haemaphysalis punctata (Tijsse-Klasen et al. 2013), which may attack humans and is recognized as existing permanently in Poland, but in West Pomerania province (Nowak-Chmura and Siuda 2012).

The lack of IGM and the presence of IgG antibodies against SFG Rickettsia in studied groups in titer 1:64 reflect infection acquired at an undetermined time. The past infection was also confirmed by negative results of the real time PCR assay. Actually, a rickettsemia has been demonstrated to occur on the first stage of the disease. None of the forestry workers and other individuals in this study reported any tick bite-related symptoms at least 6 weeks prior to the investigation, however, subclinical infection should not be excluded.

These findings confirm that rickettsial tick-transmitted agents are widely distributed in Poland and suggest that they should be taken into consideration in the differential diagnosis of febrile patients with a recent history of tick bite in the investigated area and other regions of Poland. The prevalence of rickettsial diseases in Poland is probably underestimated. To prove, however, that spotted fever rickettsioses occur in the country, the isolation of the agents from patients is needed. The results also demonstrate a need for further, more extensive studies.

Acknowledgments This study was financially supported by the Grant of Ministry of Science and Higher Education No. N404 179 040. We are grateful to Mirosława Dabert (Adam Mickiewicz University, Poznań, Poland) for sharing an ABI Prism 3130xL Genetic Analyzer for DNA sequencing.

\section{Compliance with ethical standards}

Conflict of interest The authors declare that they have no conflict of interest.

Ethical approval All procedures performed in studies involving human participants were in accordance with the ethical standards of the institutional and/or national research committee and with the 1964 Helsinki declaration and its later amendments or comparable ethical standards.

Open Access This article is distributed under the terms of the Creative Commons Attribution 4.0 International License (http://creativecommons.org/licenses/by/4.0/), which permits unrestricted use, distribution, and reproduction in any medium, provided you give appropriate credit to the original author(s) and the source, provide a link to the Creative Commons license, and indicate if changes were made.

\section{References}

Angelakis E, Pulcini C, Waton J, Imbert P, Socolovschi C, Edouard S, Dellamonica P, Raoult D (2010) Scalp eschar and neck lymphadenopathy caused by Bartonella henselae after tick bite. Clin Infect Dis 50:549-551. doi:10.1086/650172

Biernat B, Stańczak J, Michalik J, Sikora B, Cieniuch S (2016a) Rickettsia helvetica and R. monacensis infections in immature Ixodes ricinus ticks derived from sylvatic passerine birds in west-central Poland. Parasitol Res. doi:10.1007/s00436-016-5110-6 
Biernat B, Stańczak J, Michalik J, Sikora B, Wierzbicka A (2016b) Prevalence of infection with Rickettsia helvetica in Ixodes ricinus ticks feeding on non-rickettsiemic rodent hosts in sylvatic habitats of westcentral Poland. Ticks Tick Borne Dis 7:135-141

Brouqui P, Parola P, Fournier PE, Raoult D (2007) Spotted fever rickettsioses in southern and eastern Europe. FEMS Immunol Med Microbiol 29:2-12

Cardeñosa N, Sequara F, Raoult D (2003) Serosurvey among Mediterranean spotted fever patients of a new spotted fever group rickettsial strain (Bar29). Eur J Epidemiol 18:351-356

Chmielewski T, Podsiadły E, Karbowiak G, Tylewska-Wierzbanowska S (2009) Rickettsia spp. in ticks, Poland. Emerg Infect Dis 15:486-488

Cinco M, Luzzatti R, Mascioli M, Floris R, Brouqui P (2006) Serological evidence of Rickettsia infection in forestry rangers in north-eastern Italy. Clin Microbiol Infect 12:493-495

de Sousa R, Pereira PI, Nazareth C, Cabral S, Ventura C, Crespo P, Marques N, da Cunha S (2013) Rickettsia slovaca infection in humans, Portugal. Emerg Infect Dis 19:1627-1629

Dobec M, Golubic D, Punda-Polic V, Kaeppeli F, Sievers M (2009) Rickettsia helvetica in Dermacentor reticulatus tick. Emerg Infect Dis 15:98-100

Dobler G, Wölfel R (2009) Typhus and other rickettsioses. Emerging infections in Germany. Dtsch Arztebl Int 106:348-354

Dobler G, Essbauer S, Wölfel R (2009) Isolation and preliminary characterisation of 'Rickettsia monacensis' in south-eastern Germany. Clin Mirobiol Infect 15(Suppl 2):263-264. doi:10.1111/j.1469-0691.2008. 02227.x

Eremeeva ME, Dusch GA (2015) Challenges posed by tick-borne rickettsiae: eco-epidemiology and public health implications. Front Publ Health 3:55. doi:10.3389/fpubh.2015.00055

Fournier PE, Grunnenberger F, Jaulhac B, Gastinger G, Raoult D (2000) Evidence of Rickettsia helvetica infection in humans, eastern France. Emerg Infect Dis 6:389-92

Guy E, Stanek G (1991) Detection of Borrelia burgdorferi in patients with Lyme disease by the polymerase chain reaction. J Clin Pathol 44:610-611

Hechemy KE, Raoult D, Fox J, Han Y, Elliott LB, Rawlings J (1989) Cross-reaction of immune sera from patients with rickettsial disease. J Med Microbiol 29:199-202

Hofmeester TR, van der Lei PB, van Leeuven AD, Sprong H, van Wieren SE (2015) New foci of Haemaphysalis punctate and Dermacentor reticulatus in the Netherlands. Ticks Tick Borne Dis 7:367-370

Ibarra V, Oteo JA, Portillo A, Santibanez S, Blanco JR, Metola L, Eiros JM, Pérez-Martinez L, Sanz M (2006) Rickettsia slovaca infection: DEBONEL/TIBOLA. Ann N Y Acad Sci 1078:206-214. doi:10. 1196/annals.1374.040

Jado I, Oteo JA, Aldámiz M, Gil H, Escudero R, Ibarra V, Portu J, Portillo A, Lezaun MJ, García-Amil C, Rodríguez-Moreno I, Anda P (2007) Rickettsia monacensis and human disease, Spain. Emerg Infect Dis 13:1405-1407. doi:10.3201/eid1309.060186

Jansen A, La Scola B, Raoult D, Lierz M, Wichmann O, Schneider T (2008) Antibodies against Rickettsia spp. in hunters, Germany. Emerg Infect Dis 15:1961-1963

Lakos A (1997) Tick-borne lymphadenopathy—a new rickettsial disease? Lancet 350:1006. doi:10.1016/ S0140-6736(05)64072-X

Lindblom A, Wallménius K, Nordberg M, Forsberg P, Eliasson I, Påhlson C, Nilsson K (2013) Seroreactivity for spotted fever rickettsiae and co-infections with other tick-borne agents among habitants in central and southern Sweden. Eur J Clin Microbiol Infect Dis 32:317-323

Mączka I, Roguska U, Tylewska-Wierzbanowska S (2013) Prevalence of rickettsioses in Poland in 2006-2012. Przegl Epidemiol 67:633-636

Madeddu G, Mancini F, Caddeo A, Ciervo A, Babudieri S, Maida I, Fiori ML, Rezza G, Mura MS (2012) Rickettsia monancensis as cause of Mediterranean spotted fever-like illness, Italy. Emerg Infect Dis 18:702-704

May K, Strube C (2014) Prevalence of Rickettsiales (Anaplasma phagocytophilum and Rickettsia spp.) in hard ticks (Ixodes ricinus) in the city of Hamburg, Germany. Parasitol Res 113:2169-2175. doi:10. 1007/s00436-014-3869-x

Mierzejewska E, Pawełczyk A, Radkowski M, Welc-Falęciak R, Bajer A (2015) Pathogens vectored by the tick, Dermacentor reticulatus, in endemic regions and zones of expansion in Poland. Parasites Vectors 8:490. doi:10.1186/s13071-015-1099-4

Nielsen H, Fournier PE, Pedersen IE, Krarup H, Ejlertsen T, Raoult D (2004) Serological and molecular evidence of Rickettsia helvetica in Denmark. Scand J Infect Dis 36:559-563

Nilsson K (2009) Septicaemia with Rickettsia helvetica in a patient with acute febrile illness, rash and myasthenia. J Infect 58:79-82 
Nilsson K, Jaenson TGT, Uhnoo I, Lindquist O, Pettersson B, Uhlén M, Friman G, Påhlson C (1997) Characterization of the spotted fever group rickettsia from Ixodes ricinus ticks in Sweden. J Clin Microbiol 35:243-247

Nilsson L, Lindquist O, Påhlson C (1999) Association of Rickettsia helvetica with chronic perimyocarditis in sudden cardiac death. Lancet 354:1169-1173

Nilsson K, Lukinius A, Påhlson C, Moron C, Hajem N, Olsson B, Lindquist O (2005) Evidence of Rickettsia spp. infections in Sweden: a clinical, ultrastructural and serological study. APMIS 113:126-134

Nilsson K, Elfving K, Påhlson C (2010) Rickettsia helvetica in patients with meningitis, Sweden, 2006. Emerg Infect Dis 16:490-492. doi:10.3201/eid1603.090184

Nilsson L, Wallménius K, Påhlson C (2011) Coinfection with Rickettsia helvetica and herpes simplex virus 2 in a young woman with meningoencephalitis. Case Rep Infect Dis. doi:10.1155/2011/469194

Nowak-Chmura M, Siuda K (2012) Ticks of Poland. Review of contemporary issues and latest research. Ann Parasitol 58:125-155

Oteo JA, Ibarra V, Blanco JR, Martinez de Artola V, Marquez FJ, Portillo A, Raoult D, Anda P (2004) Dermacentor-borne necrosis erythema and lymphadenopathy: clinical and epidemiological features of a new tick-borne disease. Clin Microbiol Infect 10:327-331. doi:10.1111/j.1198-743X.2004.00782.X

Parola P, Rovery C, Rolain JM, Brouqui P, Davoust B, Raoult D (2009) Rickettsia slovaca and R. raoultii in tick-borne rickettsioses. Emerg Infect Dis 15:1105-1108. doi:10.3201/eid1507.081449

Podsiadły E, Chmielewski T, Karbowiak G, Kędra E, Tylewska-Wierzbanowska S (2011) The occurrence of spotted fever rickettsioses and other tick-borne infection in forest workers in Poland. Vector Borne Zoonotic Dis 7:985-989

R Development Core Team (2008) R: a language and environment for statistical computing. R Foundation for Statistical Computing, Vienna, Austria. ISBN 3-900051-07-0

Raoult D, Lakos A, Fenollar F, Beytout J, Brouqui P, Fournier PE (2002) Spotless rickettsiosis caused by Rickettsia slovaca and associated with Dermacentor ticks. Clin Infect Dis 34:1331-1336

Regnery RL, Spruill CL, Plikyatis BD (1991) Genotypic identification of rickettsiae and estimation of interspecies sequence divergence for portions of two rickettsial genes. J Bacteriol 173:1576-1589

Reye AL, Stegniy V, Mishaeva NP, Velhin S, Hubschen JM, Ignatyev G, Muller CP (2013) Prevalence of tick-borne pathogens in Ixodes ricinus and Dermacentor retculatus ticks from different geographical locations in Belarus. PLoS One 8:e54476. doi:10.1371/journal.pone.0054476

Rieg S, Schmold S, Theilacker C, de With K, Wolfe S, Kern WV, Dobler G (2011) Tick-borne lymphadenopathy (TIBOLA) acquired in southwestern Germany. (Case study). BMC Infect Dis 11:167. doi:10.1186/1471-2334-11-167

Rijpkema S, Golubić D, Molkenboer M, Verbreek-De Kruif N, Schellekens J (1996) Identification of four groups of Borrelia burgdorferi sensu lato in Ixodes ricinus ticks collected in a Lyme borreliosis endemic region of northern Croatia. Exp Appl Acarol 20:23-30

Roux V, Fournier PE, Raoult D (1996) Differentiation of spotted fever group rickettsiae by sequencing and analysis of restriction fragment length polymorphism of PCR-amplified DNA of the gene encoding the protein rOmpA. J Clin Microbiol 34:2058-2065

Rymaszewska A, Piotrowski M (2013) Use of DNA sequences for Rickettsia identification in Ixodes ricinus ticks: the first detection of Rickettsia monacensis in Poland. Microbes Infect 15:140-146

Samoylenko I, Shpynov S, Raoult D, Rudakov N, Fournier PE (2009) Evaluation of Dermacentor species naturally infected with Rickettsia raoultii. Clin Microbiol Infect 15(Suppl 2):305-306

Selmi M, Bertolotti L, Tomassone L, Mannelli A (2008) Rickettsia slovaca in Dermacentor marginatus and tickborne lymphadenopathy, Tuscany, Italy. Emerg Infect Dis 14:817-820. doi:10.3201/eid1405.070976

Severinsson K, Jaenson TG, Pettersson J, Falk K, Nilsson K (2010) Detection and prevalence of Anaplasma phagocytophilum and Rickettsia helvetica in Ixodes ricinus ticks in seven study areas in Sweden. Parsites Vectors 3:66. doi:10.1186/1756-3305-3-66

Silaghi C, Hamel D, Thiel C, Pfister K, Pfeffer M (2011) Spotted fever group rickettsiae in ticks, Germany. Emerg Infect Dis 17:890-892

Simser JA, Palmer AT, Fingerle V, Wilske B, Kurtti TJ, Munderloh UG (2002) Rickettsia monacensis sp. nov., a spotted fever group Rickettsia, from ticks (Ixodes ricinus) collected in a European city park. Appl Environ Microbiol 68:4559-4566

Siuda K (1993) Kleszcze Polski (Acari: Ixodida) [Ticks (Acari: Ixodida) of Poland. Part II taxonomy and distribution], Polskie Towarzystwo Parazytologiczne, Warszawa

Socolovschi C, Mediannikov O, Raoult D, Parola P (2009) The relationship between spotted fever group Rickettsiae and ixodid ticks. Vet Res 40:34. doi:10.1051/vetres/2009017

Sonnleitner ST, Simeoni J, Lang S, Dobler G, Speck S, Zelger R, Schennach H, Lass-Flörl C, Walder G (2013) Spotted fever group-rickettsiae in the Tyrols: evidence by seroepidemiology and PCR. Zoon Publ Health 60:284-290 
Sormunen JJ, Penttinen R, Klemola K, Hänninen J, Vuorinen I, Laaksonen M, Sääksjärvi IE, Ruohomäki K, Vesterinen J (2016) Tick-borne bacterial pathogens in southwestern Finland. Parasites Vectors 9:168. doi:10.1186/s13071-016-1449-x

Špitalská E, Stefanidesová K, Kocianová E, Boldiš V (2012) Rickettsia slovaca and Rickettsia raoultii in Dermacentor marginatus and Dermacentor reticulatus ticks from Slovak Republic. Exp Appl Acarol 57:189-197. doi:10.1007/s10493-012-9539-8

Špitalská E, Stanko M, Mošanský L, Kraljik J, Miklisová D, Marhíková L, Bona M, Kazímirová M (2016) Seasonal analysis of Rickettsia species in ticks in agricultural site of Slovakia. Exp Appl Acarol 68:315-324

Sprong H, Wielinga PR, Fonville M, Reusken C, Brandenburg AH, Borgsteede F, Gaasenbeek C, van der Giesen JWB (2009) Ixodes ricinus ticks are reservoir hosts for Rickettsia helvetica and potentially carry flea-borne Rickettsia species. Parasites Vectors 2:4. doi:10.1186/1756-3305-2-41

Sréter-Lancz Z, Széll Z, Kovács G, Egyed L, Márialigeti K, Sréter T (2006) Rickettsiae of the spotted fever group in ixodid ticks from Hungary: identification of a new genotype ('Candidatud Rickettsia Kotlanii'). Ann Trop Med Parasitol 100:229-236

Stańczak J (2006) Detection of spotted fever group (SFG) rickettsiae in Dermacentor reticulatus (Acari: Ixodidae) in Poland. Int J Med Microbiol 296(Suppl 40):144-148

Stańczak J, Racewicz M, Michalik J, Buczek A (2008) Distribution of Rickettsia helvetica in Ixodes ricinus tick populations in Poland. Int J Med Microbiol 298(Suppl 1):231-234

Stańczak J, Racewicz M, Michalik J, Cieniuch S, Sikora B, Skoracki M (2009) Prevalence of infection with Rickettsia helvetica in feeding ticks and their hosts in western Poland. Clin Microbiol Infect 15(Suppl 2):328-329

Švehlová A, Berthová L, Sallay B, Boldiš V, Sparagano OAE, Špitalská E (2014) Sympatric occurrence of Ixodes ricinus, Dermacentor reticulatus and Haemaphysalis concinna ticks and Rickettsia and Babesia species in Slovakia. Ticks Tick Borne Dis 5:600-605

Świtaj K, Chmielewski T, Borkowski P, Tylewska-Wierzbanowska S, Olszyńska-Krowicka M (2012) Spotted fever rickettsiosis caused by Rickettsia raoultii-case report. Przegl Epidem 66:347-350

Tijsse-Klasen E, Jameson LJJ, Fonville M, Leach S, Sprong H, Medlock YM (2011) First detection of spotted fever group rickettsiae in Ixodes ricinus and Dermacentor reticulatus ticks in the UK. Epidemiol Infect 139:524-529

Tijsse-Klasen E, Hansford KM, Jahfari S, Phipps P, Sprong H, Medlock YM (2013) Spotted fever group rickettsiae in Dermacentor reticulatus and Haemaphysalis punctata ticks in the UK. Parasites Vectors 6:2012. http://www.parasitesandvectors.com/content/6/1/212

Welc-Falęciak R, Kowelec M, Karbowiak G, Bajer A, Behnke JM, Siński E (2014) Rickettsiaceae and Anaplasmataceae infections in Ixodes ricinus ticks from urban and natural forested areas of Poland. Parasites Vectors 7:121. http://www.parasitesandvectors.com/content/7/1/121

Wójcik-Fatla A, Cisak E, Zając V, Sroka J, Sawczyn A, Dutkiewicz J (2013) Study on tick-borne rickettsiae in eastern Poland: I. Prevalence in Dermacentor reticulatus (Acari: Amblyommidae). Ann Agric Environ Med 20:276-279

Zając V, Wójcik-Fatla A, Cisak E, Sroka J, Sawczyn E, Dutkiewicz J (2013) Study on tick-borne rickettsiae in eastern Poland. II. Serological response of occupationally exposed population. Ann Agric Environ Med 20:280-282 